Available online: 26. October 2017

\title{
REAL DEMOGRAPHIC LOSSES OF MONTENEGRO CAUSED BY WARS IN THE $20^{\mathrm{TH}}$ CENTURY
}

\author{
Jovo Medojević*, Mila Pavlović* ${ }^{*+1}$ \\ "University of Pristina - Faculty of Sciences and Mathematics, Kosovska Mitrovica \\ "University of Belgrade - Faculty of Geography, Belgrade
}

\begin{abstract}
The aim of this paper is to research demographic losses of Montenegro during the wars of the 20th century: Balkan Wars, First World War and the Second World War. Authors have analysed available data on demographic losses of Montenegro and have made critical researchin which they pointed out to all deficiencies and oversights in war victims Censuses which were carried out after the end of the Second World War.
\end{abstract}

Key words: demographic losses, Montenegro, wars in the 20th century, war victims, censuses.

\section{Introduction}

Demographic theory and practice indicate that war conflicts are the most important external factors of demographic development. Wars, due to their longevity and diversity, represent a significant factor in the development of society. War conflicts affect on the negative demographic processes that are most pronounced in the population growth and migration of the population, as well as onthe depopulation processes. These processes are expressed not only during the war but also in the post-war period.

${ }^{1}$ Corresponding author: M. Pavlović, University of Belgrade - Faculty of Geography, Studentski trg 3/III, 11,000 Belgrade, Serbia; e-mail: mila.pavlovic2@gmail.com 


\section{Overview of previous research}

The problem of demographic losses in the wartime has been research subject of many scientific papers (Radivojević and Penev 2014; Živić, 2006; Vandenbroucke, 2012; Kugler, et. al., 2013; Zwierzchowski, and Tabeau 2010; Roberts, 2010; Sokolov, 2009; Sokolov, 2014; Tabeau, 2009; Ismailov, 2011).

The demographic development of Montenegro during the 20th century was under the strong and dominant influence of war conflicts: the Balkan Wars (Ratković, Đurišić and Skoko, 1972), the First World War (Rakočević, 1969) and the Second World War. Therefore, the study of demographic war losses in Montenegro is an important historical-demographic area of study. The research on the size and structure of demographic losses imposes itself as the dominant issue of the impact of wars on the overall demographic and regional development of Montenegro.

In the past 105 years, since the First Balkan War, the number of war victims in Montenegro has been interpreted differently. Whether deliberately or not, the number of real victims in the Balkan Wars and the First World War is approximate to the real state. However, the number of victims of the Second World War have been rapidly reduced over time. The prominent war victims researcher, Bogoljub Kočović, points out (Kočović, 1990) that the reduction of the number of victims is often criticized, especially in the Second World War. Many researchers say that reducing the number of victims is "equal to sin or betrayal." (Kočović, 1990). However, on the other hand, reducing or increasing the number of victims, says Kočović, means that the perpetrators know the exact number of actual victims, because it decreases or increases from one specific figure, which is determined. This determined number of war victims (according to Kočović) does not exist and will never exist; especially not today after one century from the Balkans Wars and the First World War and 72 years since the Second World War (Kočović, 1990). A specific problem in the study of demographic victims is the fact that the country has changed its external borders several times in the period 1912-1945.

\section{The concept and methodology of researching victims of war and demographic war losses}

What is the definition of victims of war, real demographic losses and total demographic war losses? The term "victims of war", as basic statistical and demographic methodological term, means "every person who has 
been killed, died, disappeared, imprisoned, deported, taken to forced labor, captured or survived the war terrors (Republički zavod za statistiku (RZS), 1966). The term real demographic losses is defined as all military and civilian victims of war who have lost their lives. So, allvictims who lost their lives in military operations, who were killed in camps and prisons, deportations, victims of war wounds or illnesses (Врућинић, 2007). The term "total demographic losses is defined as the difference between the expected/projected number of inhabitants in Montenegro, assuming that there was no war and taking into account the number of inhabitants in the territory of Montenegro established by the first post-war census (Врућинић, 2007).

The researchers agree (e.g. Lah, 1952; Tasić, 1951) in one, that determination of direct demographic losses is not only very difficult, but to a certain extent is almost impossible. We can count a number of persons who lost their lives in the war or migrated because of the war, but we cannot count the unborn children, or to be exact children who would be born in peacetime. Likewise, we cannot count the persons who lost their lives during the war, who would otherwise die in normal circumstances in a certain period even if there was no war. Our research has focused on the study of actual demographic losses that include: persons who were killed or died due to war (wounds, illness, accidents, etc.) and those who are referred to as direct human casualties or war mortality, as well as population losses caused by increased emigration due to warfare (refugees).

\section{The research results and discussion}

In order to determine the real demographic losses in Montenegro, reliable statistics are necessary, that is, archival sources that deal with this issue and problems in a direct way. This implies accurate demographic-statistic data, that is, time series that are handled in absolutely correct, truthful and reliable manner by the vital static parameters of the population of Montenegro. Why do we emphasize "absolutely correct, truthful and reliable" statistics? Today's research on demographic losses in Montenegro in the wars of the 20th century is largely hampered. They are hampered because of the lack of a list of victims. The data we have are factual, according to some authors, and all of these data give us many reasons to suspect their truthfulness.

During the Balkan Wars and the First World War, there are no data on the vital statistics of the population of Montenegro. Census of Principals of Montenegro from 1879, and the 1910 Census, do not give the opportunity to 
carry out demographic projections and forecasts on demographic losses in Montenegro for the indicated period. First, in the observed period, Montenegro changed its external borders and structure of its administrative units several times. In the population census of 1910, there were 100,000 inhabitants more than Montenegro actually had in 1910 (Đurić, 1924). In these circumstances, accurate scientific analyses is not possible. In Montenegro from 1912 to 1918, there was no serious state registration of vital events: number of births, number of deaths; as well as the population structures. The director of the Statistical office of the Kingdom of Serbs of Croats and Slovenians, Dr Dragiša Đurić, points out that in Montenegro there were no data on the population growth (Đurić, 1924).

\section{Demographic losses caused by the Balkan Wars and the First World War}

One of the most famous and most frequently quoted estimates of demographic losses caused by the First World War, for Northern Serbia and Montenegro, was done by the demographic research team of Princeton University in 1944. The research was led by Franck Notestain. A study was published in Geneva in 1944 under the title The future population of Europe and the Soviet Union - projections 1940-1970 (Notestein, 1944). In fact, Princeton University has done a projection of the population of Europe and the Soviet Union for the period 1940-1970. Among European countries, Yugoslavia was also included.

Princeton demographers have raised doubts regarding the reliability of demographic projections for Yugoslavia, due to the inadequacy and unreliability of statistical data; so they have used the original analytical method based on hypotheses: mortality and fertility fall rapidly when they are at high level, but slow when they are small, that the mortality and fertility ratio is approximately constant regardless of the time period and regardless of population. Their hypothesis was that wars only transiently change fertility and mortality (Notestein, 1944). A few years after the end of the wars, (case of Montenegro), the decline in mortality in the pre-war trend continues, as if there was no wartime. The estimation of demographic losses for the First World War was done using several methods: vital-statistical, average birth and death rates, analytical methods and inductive methods. Demographic losses for the Kingdom of Serbia and the Kingdom of Montenegro are estimated at 1.064 .000 casualties. These losses include military losses and excess civilian deaths of persons older than one year and alsoreduced birth rates. Demographic losses relate to the period 1914-1919. Military losses are estimated at 325.000, representing about 
$10 \%$ of the pre-war population. Princeton University emphasizes that the estimated military losses of Serbia and Montenegro are enormous, although they included missing military personnel who are presumed dead (Врућинић, 2007). It is assumed that the report of the Government of the Kingdom of Serbs, Croats and Slovenians which was submitted to Geneva in 1924, probably also included war losses from the Balkan wars. Many researchers agree that Princeton University estimates are real (Врућинић, 2007).

According to this assessment, in 1910, the total population in Montenegro was 238.000. During the First World War, Montenegro had military losses of 25.000 soldiers and 34.000 civilian casualties caused by the war. Reduced birth by 25.000; a reduction of 4.000 due to infant death, which makes the demographic loss of Montenegro during the Balkan and First World War of 80,000 inhabitants or $33.78 \%$ of the total population. Demographic losses were obtained by adding up the value of military losses, the surplus of civilian deaths, and the difference between values for reduced birth and presumed infant mortality. If we assume that the demographic losses of Northern Serbia and Montenegro in the relative number are equal, then in proportion to the number of inhabitants from 1910, we can conclude that Montenegro in proportion to the number of inhabitants, suffered the largest demographic losses in the First World War, losing more than $1 / 3$ of the entire population.

In 1924, Dr Dragiša Đurić assessed the demographic losses of Montenegro, North Serbia and South Serbia caused by the Balkan Wars and World War I. It is important to note that at that time, four districts were included within the South Serbia, regardless of the established borders of the Bucharest Peace Treaty of 1913. These districs are: Metohija, Berane, Bijelo Polje and Pljevlja, altough Montenegro gained these districs form Turkey during the Balkan Wars. So Đurić has made an assessment for Montenegro in relation to the borders of 1912 (Врућинић, 2007). The demographic losses of the Kingdom of Serbia and the Kingdom of Montenegro together amount to over 1.200.000 casualties. Number of inhabitants for Montenegro for 1914 was obtained on the basis from the reports of Government of Montenegro (Rus, 1920).

\section{Demographic losses caused by the Second World War}

The Second World War is one of the world's largest conflicts in terms of its duration, the number of countries that participated, destruction, and especially demographic losses. An International reparations commission in Paris was given the data on 1.706.000 dead in Yugoslavia during the Second 
World War, including 305.000 dead partisan fighters. These are the data of the State Commission for Determining the Crimes of the Occupation and their Assistants (which was formed in 1943 at the second session of AntiFascist Council for the National Liberation of Yugoslavia).

In the month of November 1964, a census of victims of the war from 1941-1945 was carried out on the territory of the entire SFRY.The decision on the census was made by the Federal Executive Council, and the organization and the execution of the census were managed by census commissions, republics, districts and municipalities. The Committees were mostly represented by veterans and other socio-political organizations, representatives of social-political communities and the Army.Also, the statistical organizations, as carriers of a professional part at all stages of the work, also played an active role in the census. Over 30,000 persons participated in the organization and implementation of the Census, of which 25.000 were enumerators. Official data indicates that the census was not implemented equally in all areas, as there were objective difficulties in the implementation of the list of victims, especially due to the intensive migration that existed in the country from 1945 to the 1964.Thus, the list, especially in Slovenia, Bosnia and Herzegovina and Croatia, was carried out, mainly by visiting all households, which was not the case with households in Montenegro. This was determined by the subsequent checking of the list of victims (the rule is to check the list by random sample). Hence, the Census was extended by the end of April 1965, however, the overall effect of all checks and supplementary actions minimally changed the previous results (RZS, 1966).

The results of the census showed that total of 1.007 .172 casualties were recorded, of which 597,323 lost their lives and 509,849 were war survivors. According to this Census, Montenegro officially had 16.903 victims who lost their lives, of which men were 13.336 with a relative share of $79,06 \%$ and 3.540 women accounting for $20.94 \%$ of their participation in the total number of World War II victims. The Census included victims who have lost their lives in the internment, in prison, in deportation, in forced labor, in direct terror, in prison (as members of the former Yugoslav Army and members of the Yugoslav Partisans), and victims of war who lost their lives in the battles from July 7, 1941 as Yugoslav Partisans and allied military formations, during the battle and bombing. Our research describes all methodological framework for victims of war in all municipalities in Montenegro: Bar, Bijelo Polje, Budva, Cetinje, Danilovgrad, Herceg Novi, Ivangrad (Berane), Kolašin, Kotor, Mojkovac, Nikšić, Plav, Plužine, Pljevlja, Rožaje, Šavnik, Titograd (Podgorica), Tivat, Ulcinj, Žabljak, as well as victims of the war from 
an unknown municipality, including survivors of war: internal prisoners, prisoners, deportees and prisoners of war (including force labor). Also, we have processed all the demographic structures of the victims of war: by age groups, by ethnicity, by occupation (RZS, 1966).

The selected dated show that share of male population of Montenegro in the age of 15 to 44 years, was $68 \%$ or 11.489 in the total number of victims. The largest number of victims was recorded in the age between $15-24$ years (5.605 or $33 \%$ of the total number of victims). The number of children under the age of 14 who have died during the War is also very high (2.011 or 11,89\%) (RZS, 1966).

On this occasion, we point out to a forgotten Census, which is crucial source of information about victims of war in Montenegro during the World War II. The results of this Census are not comparable to the 1964 Census. This is a Census of the Reparation Commission of the Government of the FPRY. In the period between October 1945 and March 1946, the Repatriation Commission listed all victims of war and material damage through the local National Committees and the War Commission for War Damage. The Census is factually very comprehensive. This Census also has its visible deficiencies, especially regarding the list of material losses and furnishing and the description of the perpetrator for material damage. There are also a number of mistakes in the victims' war data. Errors appear in the "Report of deprivation of life", e.g. a mistake in the place of residence prior to death or disappearance, occupation, error in the date of deprivation or disappearance. However, the coverage (data) of victims of war is comprehensive and can be said to be complete. Unfortunately, the archival material about this Census was in most cases destroyed or disappeared. The complete archive material for District of Bijelo Polje was preserved, which then included in addition to today's municipality of Bijelo Polje and part of today's municipality Mojkovac with following villages: Prošćenje, Stevanovac, Lepenac, Žari and Mojkovac grad; therefore, the Census boundary of the District of Bijelo Polje was the right bank of the Tara river.Comparing the list of war victims of the 1946 District Commission for War Damage and the 1964 War Victims Census, we notice a huge difference. In Bijelo Polje, a total of 1,542 victims (military and civilian) were recorded, while 3,758 victims were registered in the Bijelo Polje district census in 1946, which makes a difference in the 2,216 victims of the Second World War (only observed) in the area of Bijelo Polje.

After the Second World War, several estimates of the demographic losses of Yugoslavia (including Montenegro) were made. The University of Princeton estimated the immediate loss of 1.000 .000 and demographic loss 
of 1.200.000; researcher Ivo Lah, estimated an 1.400.000 direct war losses, and 2.100.000 demographic losses (Lah, 1952). Dragoljub Tasić estimates the 1.500.000 direct war losses and a demographic loss of 2.428 .000 inhabitants (Tasić, 1951). Grigorij Frumkin (Frumkin, 1951) did not give an estimate of demographic losses, but estimates that the direct war losses of Yugoslavia are 1.500.000. Dolfe Vogelnik presented the highest estimate of $1.800 .000 \mathrm{di}-$ rect war losses and 2.854.000 casualties as the demographic loss of Yugoslavia in World War II (Vogelnik, 1952). In the professional and scientific public, special attention is devoted to research by Bogoljub Kočović "Victims of the Second World War in Yugoslavia" (Kočović, 1990).

All these estimates of the number of the war victims are based on the estimated number of population by sex and age for 1948, calculated on the basis of available data on the number of inhabitants from the census of 1931 and 1948, and data on fertility and mortality during that period. However, the 1948 population estimates and the actual census of 1948 indicate to the estimator's error of reduction the total population by 2.100 .000 inhabitants. The estimate of the total population for 1948 was 17.809.642, and the actual census results indicated a total of 15.753.132. inhabitants. The Federal Census Commission of War Victims assessed that the census covered between $60 \%$ and $65 \%$ of victims of war and that the obtained data on war victims were defective, but that they would meet the existing purposes. Kočović and Žerjavić have made the assessments of victims of war in Montenegro. According to Kočović the number of victims is 50.000 (Kočović, 1990), and by Žerjavić 20.000 (Žerjavić, 1989). It is interesting that the victims of the war in Montenegro differ in the author's estimates by 30,000.

We can say that during the Second World War Montenegro had a real demographic loss of 50.000 inhabitants. While the demographic loss amounted to 112.000 inhabitants, which represented a total demographic loss of $33.1 \%$ of the population in the period from 1941 to 1948 . If we include the migration of 38,000 inhabitants of Montenegro to Vojvodina after the Second World War, as a result of the war, the demographic loss of Montenegro would amount to 150.000 inhabitants.

\section{Conclusion}

Human losses, both military and civil, in the war and post-war period, cause numerous, long-term and complex demographic and social processes. The Censuses of victims of war in Montenegro and their demographic analysis 
indicate to severe demographic consequences. (although Montenegro had a number of changes in external borders and internal administrative changes in the period from 1909 to 1945). There is a scientific and professional gap in the study of the victims of war in Montenegro because victims and demographic losses have not been dealt with either sociologically or from a historical point of view, nor from a psychological aspect. In future research on demographic losses in Montenegro, a substantiated scientific answer must be given to the question of the actual demographic losses in Montenegro in all wars of the 20th century. Not only because of the number manipulation, but in honour of all victims of war in Montenegro. It is necessary to open a debate on this issue, especially regarding the number of victims during the Second World War.

In spite of the obvious numerous shortcomings in the censuses, unreliable war records of injured soldiers and civilians, mistakes in the memory, bias, the lists of victims of wars in Montenegro are not final. After Lah's research, published in 1952 on demographic losses in Yugoslavia, the demographic polemics have completely stopped. Most of the demographic losses estimates for the Second World War came from the population census of 1931 and 1948. The authors have made different estimates of birth deficits due to the war and the number of those who left the country during and immediately after the war.

Our research indicates that the demographic loss of Montenegro in the Balkan and First WorldWar amounted to 80.000 inhabitants or $33.78 \%$ of the total population in Montenegro. The demographic losses of Montenegro in the Second World War amounted to 112.000 inhabitants. We can conclude that Montenegro in the 20th century had a demographic loss of 192.000 inhabitants. In we include the emigration to Vojvodina of 38.000 migrants, the overall demographic loss of Montenegro in the period from 1912 to 1948 can be estimated at 230.000 inhabitants. The results of the research indicate that no country in the world, compared to the total population, has experienced such a demographic loss as Montenegro during the wars and consequences of the wars in the 20th century. Montenegro had a demographic loss of $62 \%$ of the total population. The relatively large demographic losses of Montenegro as a result of the aforementioned war conflicts have determined a number of population disorders, especially when it comes to the population growth and migration movements after the Second World War.

\section{Acknowledgements}

The paper is the result of the research within the project no. 176008 funded by the Ministry of Education and Science of the Republic of Serbia. 


\section{References}

Državni arhiv Crne Gore. Arhiv Cetinje (2009). Popis stanovništva Knjaževine Crne Gore 1879. Cetinje.

Državni arhiv Crne Gore. Arhivsko odjeljenje Bijelo Polje, Fond: Žrtve rata 1941 - 1945. godine.

Đurić, D. (1924). Uvod u prethodne rezultate popisa stanovništva Kraljevina SHS, 31. januara 1921. Sarajevo: Državna štamparija.

Frumkin, G. (1951). Population changes in Europe since 1939: a study of population changes in Europe during and since World War I as shawn by the balance sheets of twenty-four European countries. London: Allen \& Unwin.

Ismailov, A. I. (2011). On the issue of human losses during the Great Patriotic War, 1941-1945. Journal of Slavic Military Studies, 24(2), 232-237. doi:10.1080/13518046.2011.572717

Kočović, B. (1990). Žrtve Drugog svetskog rata u Jugoslaviji. Sarajevo: Svjetlost.

Kugler, T., Kook Kang, K., Kugler, J., Arbetman-Rabinowitz, M., \& Thomas, J. (2013). Demographic and economic consequences of conflict. International Studies Quarterly, 57(1), 1-12. doi:10.1111/isqu.12002

Lah, I. (1952). Istinski demografski gubici Jugoslavije u Drugom svetskom ratu. Statistička revija, $2(2,3)$.

Notestein, F. (1944). The future population of Europe and Soviet Union projections 1940-1970. Geneva: League of Nations.

Radivojević, B. and Penev, G. (2014). Demographic losses of Serbia in the first world war and their long-term consequences. EconomicAnnals, 59(203), 29-54.

Rakočević, N. (1969). Crna Gora u Prvom svjetskom ratu. Cetinje: Istorijski institut.

Ratković, B. Đurišić M. and Skoko S. (1972). Srbija i Crna Gora u Balkanskim ratovima 1912 -1913. Beograd: Beografski izdavačko-grafičički zavod.

Republički zavod za statistiku, SFRJ Savezni zavod za statistiku (1966). Žrtve rata 1941-1945. Beograd.

Roberts, A. (2010). Lives and statistics: Are 90\% of war victims civilians? Survival, 52(3), 115-136. 
Rus, J. (1920). Glavni statistički podaci o državi Srba, Hrvata i Slovenaca prema stanju od 1910. odnosno 1914. godine. Ljubljana: Učiteljska tiskarna.

Sokolov, B. (2009). How to calculate human losses during the Second World War. Journal of Slavic Military Studies, 22(3), 437-458. doi:10.1080/13518040903084857

Sokolov, B.V. (2014). Estimating Soviet war losses on the basis of Soviet population censuses. The Journal of Slavic Military Studies, 27(3), 467-492. doi:10.1080/13518046.2014.932637

Tabeau, E. (2009). Rat u brojkama: demografski gubici u ratovima na teritoriji bivše Jugoslavije od 1991. do 1999.: glavni izveštaji demografskih veštaka predstavljeni od strane tužilaštva na suđenjima u Međunarodnom krivičnom sudu za bivšu Jugoslaviju. Beograd: Helsinški odbor za ljudska prava u Srbiji.

Tasić, D. (1951). Uvod u konačne rezultate popisa stanovništva od 15. marta 1948. godine, knjiga 1, Stanovništvo po polu i domaćinstva. Beograd: Savezni zavod za statistiku I evidenciju, FNRJ.

Vandenbroucke, G. (2012). On a demographic consequence of the First World War. http://voxeu.org/article/demographic-consequence-first-world-war

Vogelnik, D. (1952). Demografski gubici Jugoslavije u Drugom svetskom ratu. Statistička revija, 2 (1).

Zwierzchowski, J., \& Tabeau, E. (2010). The 1992-95 war in Bosnia and Herzegovina: census-based multiple system estimation of casualties' undercount. Berlin: Households in Conflict Network and Institute for Economic Research.

Žerjavić, B. (1989). Gubici stanovništva Jugoslavije u Drugom svetskom ratu. Zagreb: Jugoslavensko viktimološko društvo.

Živić, D. (2006). Problems with reasearch of demographic losses in Croatia during World War II and the post-war period. Diacovensia, 14(1), 7-29.

Врућинић, Д. (2007). Демографски губици Србије проузроковани ратовима у 20. веку. Београд: Музеј жртава рата. 